\title{
Psykisk sykdom etter fødsel
}

Denne kasuistikken illustrerer flere viktige forhold knyttet til affektiv sykdom etter fødsel. Den gir et godt eksempel på hvorledes symptomutviklingen kan være og hvordan tilstanden raskt kan forverres. Betydningen av anamnestiske opplysninger for en presis diagnose blir understreket. De behandlingsmessige dilemmaene blir ekstra vanskelige når pasienten ikke er samtykkekompetent, som i dette tilfellet.

Her velger man først en nokså tradisjonell tilnærming med behandling med antipsykotika i betydelige doser, men uten noen åpenbar behandlingseffekt. Ved elektrokonvulsiv behandling (ECT) beskrives så en overveldende effekt; pasienten klarner raskt til, symptomene avtar slik at kvinnens psykiske tilstand normaliseres, og få bivirkninger beskrives. Dette er tankevekkende og gir grunnlag for å reflektere over om denne typen behandling burde ha vært benyttet tidligere i sykdomsforløpet samt generelt om hvilken plass slik terapi bør ha ved alvorlig affektiv sykdom etter fødsel.

Et hovedtema har vært om behandlingen kan benyttes som førstehåndsbehandling eller om den skal reserveres for pasienter som ikke har respondert på andre intervensjoner som medikasjon og psykoterapi $(1,2)$.

Ved alvorlig psykisk lidelse etter fødsel er funksjonsevnen ofte sterkt nedsatt. Hos rundt $10-25 \%$ av kvinnene henvist til psykiater etter fødsel rapporteres forstyrret mor-barn-kontakt (3). Effektiv biologisk behandling som elektrokonvulsivterapi bør vurderes tidlig i forløpet eller som førstehåndsbehandling (4).

Alvorlig affektiv lidelse etter fødsel er ofte bipolare sykdomsepisoder (5). Elektrokonvulsiv behandling beskrives generelt som en av de mest effektive akuttbehand- linger for både depressiv og manisk fase av bipolar sykdom (6). Det mangler randomiserte studier av denne behandlingen blant kvinner med alvorlig affektiv lidelse etter fødsel, men gjennom en årrekke har erfarne klinikere og forskere angitt at den kan være spesielt effektiv ved slike tilstander $(4,7,8)$

En ledende fagperson innen feltet, Ian Brockington, beskriver at elektrokonvulsiv behandling kan ha en nærmest «magisk» effekt hos enkelte pasienter med postpartumdepresjon (9). Undertegnedes kliniske erfaring med elektrokonvulsiv behandling og kasuistikkrapporter fra tallrike kolleger opp gjennom årene peker i samme retning, både når denne behandlingen har vært førstevalg og i de tilfellene der psykofarmaka har vist seg utilstrekkelig.

Affektive lidelser etter fødsel er alvorlig sykdom, spesielt der det forekommer psykotiske symptomer eller suicidalfare. Ved disse tilstandene er det nødvendig med rask diagnose og effektiv behandling. Det synes å være empirisk støtte for at effekten av elektrokonvulsiv behandling nettopp kan bidra til kortere sykdomsforløp, redusert suicidalrisiko og mindre lidelsestrykk.

\section{Jan Øystein Berle}

jaob@helse-bergen.no

Forskningsenheten Sandviken

Haukeland universitetssykehus

Jan Øystein Berle (f. 1952) er overlege dr.med. ved Forskningsenheten Sandviken.

Oppgitte interessekonflikter: Forfatteren har mottatt foredragshonorar fra Eli Lilly Norge, Bristol Myers Squibb og AstraZeneca, dessuten reisestøtte fra Eli Lilly Norge.
Litteratur

1. The practice of electroconvulsive therapy: Recommended for treatment, training, and privileging. 2. utg. Washington, DC: American Psychiatric Publishing, 2001

2. Practice Guideline for the Treatment of Patients With Major Depressive Disorder. 2. utg. American Psychiatric Association Practice Guidelines. www.psychiatryonline.com/pracGuide/ loadGuidelinePdf.aspx?file=MDD2e_05-15-06 1.9. 2008

3. Brockington IF. Diagnosis and management of post-partum disorders: a review. World Psychiatry 2004: 3: 89-95

4. Berle Jø. Alvorlig depresjon og psykose post partum-når bør elektrokonvulsiv behandling brukes? Tidsskr Nor Lægeforen 1999: 119: 3000-3.

5. Bratfos O, Haug JO. Puerperal mental disorders in manic-depressive females. Acta Psychiatr Scand 1966; 42: 285-94.

6. Goodwin FK, Jamison KR. Manic-depressive illness: bipolar disorders and recurrent depression. 2. utg. New York: Oxford University Press, 2007: 314-5.

7. Reed P, Sermin N, Appleby L et al. A comparison of clinical response to electroconvulsive therapy in puerperal and non-puerperal psychoses. J Affect Disord 1999: 54: 255-60.

8. Rabheru K. The use of electroconvulsive therapy in special patient populations. Can J Psychiatry 2001 46: $710-9$

9. Brockington IF. Motherhood and mental health. New York: Oxford University Press, 1996: 180.

Mottatt 7.11. 2011, første revisjon innsendt 7.12. 2011, godkjent 14.12. 2011. Medisinsk redaktør Mette Sagsveen. 